\title{
CURRENT ISSUES OF COUNTERACTION AGAINST ILLEGAL CIRCULATION OF DRUGS USING THE INTERNET
}

\author{
Anatolii V. Movchan ${ }^{1}$ \\ Mykola O. Yankovyi ${ }^{2}$ \\ Karen Yu. Ismailov ${ }^{3}$ \\ Elena O. Melnikova ${ }^{4}$ \\ Oleksandr M. Zaiets ${ }^{5}$
}

\begin{abstract}
The relevance of the study is due to the change of activity of organized criminal groups involved in the circulation of psychoactive substances towards the organization of the mentioned activity through the Internet. The article is an examination of current problems of combating drug trafficking by using the Internet. The purpose of this work is to investigate the current problems of combating drug trafficking by using the worldwide web through contactless sale of narcotic drugs and psychotropic substances.
\end{abstract} To achieve this goal, a number of methods were used, namely: theoretical - to study and analyze statistical information, scientific and methodological literature, generalization of information to determine the theoretical and methodological bases of

the study; logical analysis - to formulate basic concepts and conduct classification; specifically historical - to demonstrate the dynamics of development; dialectics - to determine the content and features of the constituent elements; empirical methods to summarize the experience. The materials of the article are of practical value for the higher education graduates of police specialties, police officers of the criminal block and specialists in the field of operational search activities.

Keywords: drug trafficking, narcotics, online shop, bookmark, analytical intelligence.

\section{Introduction}

Lviv State University of Internal Affairs, Horodotska Str. 26, Lviv, 79007, Ukraine. E-mail: ${ }^{1}$ prof.movchan37@uohk.com.cn

Odesa State University of Internal Affairs, Uspenska Str. 1, Odesa, 65014, Ukraine ${ }^{2}$

Odesa State University of Internal Affairs, Uspenska Str. 1, Odesa, 65014, Ukraine ${ }^{3}$

Odesa State University of Internal Affairs, Uspenska Str. 1, Odesa, 65014, Ukraine ${ }^{4}$

Odesa State University of Internal Affairs, Uspenska Str. 1, Odesa, 65014, Ukraine ${ }^{5}$ 
Drug addiction and drug crime is a complex problem of modern Ukrainian society that has social, economic, legal, medical and other aspects. Effective counteraction to drug addiction and drug crime in the current environment is possible only through a comprehensive approach to solving two urgent problems: on the one hand - ensuring the appropriate level of legislative regulation of the circulation of drugs containing narcotic drugs, psychotropic substances and precursors, which would protect the interests of Ukrainian citizens. quality medical care for people suffering from drug addiction and, on the other, creating an effective system for preventing drug trafficking Psychotropic substances and precursors drugs that contain them, and their use is not for medical treatment and prevention of substances prohibited for use, termination of Transnational Crimes.

\section{European Union legislation} introduced the concept of "new psychoactive substances" in 2005 and introduced a system of information exchange regarding such substances (Council Decision..., 2005). In the current circumstances, the circulation of new psychoactive drugs marketed as illicit drugs such as cannabis, meth, cocaine, ecstasy, heroin and benzodiazepines are turning into a global problem. The number of such substances is increasing rapidly each year, exceeding the capacity to control them nationally and internationally (EU Drug Markets Report, 2016).

That is why the main tasks of the State Drug Policy Strategy for the period up to 2020, approved by the Decree of the Cabinet of Ministers of Ukraine No 735-p (2013), are aimed at solving systemic issues of medical, social, economic and law enforcement. It should be noted that in the sphere of circulation of narcotic drugs, psychotropic substances and precursors, Ukraine adheres to the following principles in shaping the state drug policy:

- public health is a priority of public policy, so drug addicts are provided with the necessary set of preventive and curative measures;

- ensuring that the population has access to vital medicines, including painkillers;

- abandoning the punitive approach to drug users;

- improvement of the activity of law enforcement agencies in the fight against organized drug crime, money laundering obtained from the illegal distribution of drugs (Degree of the Cabinet..., 2013). 
Today there is a process of informatization of the society, which is accompanied by an increase in the number of direct and hidden illegal actions of offenders in cyberspace. For example, such as electoral interference (USA, France, Germany), computer viruses (Wanna Cry, MiniDuke, BlackEnergy), or computer fraud (vishing, smashing, skimming, trapping, phantom, tent, shimming, trashing, phishing). So, now the activities of organized criminal groups involved in the circulation of new psychoactive substances, fundamentally different from the activities of "traditional" organized groups of drug business engaged in the sale of drugs of natural origin. Unlike drugs such as heroin, the production of which is a lengthy process, synthetic drugs are manufactured quickly in simple laboratories, and the formulation of their manufacture is available on the Internet. It is quite difficult to bring criminals involved in the circulation of new psychoactive substances to criminal liability because of the fact that these substances are either out of control or masked under uncontrolled substances, and their identification is difficult or often impossible.

One of the most pressing problems in combating drug trafficking is that noncontact sales of narcotic drugs and psychotropic substances using the Internet, but also through channels in the Telegram messenger, have become quite widespread in recent years, with a view to marketing laws, drug advocacy. For example, the channel in the Telegram DrugStat (2019) messenger has 48.000 subscribers and provides clear guidance on how to organize a drug business on the Internet, detailing the responsibilities of each group member, location, and other useful information for people who engage in or want to engage in illegal activity. And the mentioned organizational and methodical information is provided along with quite interesting statistics and easy-to-read texts. Although the channel itself states that it is a research project, it does not call for use and even warns of criminal responsibility for the sale of drugs.

It should be noted that, in accordance with Art. 17 of the Constitution of Ukraine information security is the most important function of the state along with the protection of sovereignty and territorial integrity and ensuring the economic security of the country (Constitution of Ukraine, 1996). Therefore, based on the existing threats, the executive bodies of Ukraine should have a proper organizational and legal mechanism to restrict the dissemination of illegal 
information on the World Wide Web, and the legislature should accordingly create the appropriate legal framework for this.

\section{Materials and Methods}

The purpose of this work is to investigate the current problems of combating drug trafficking using the Internet. To achieve this goal and for the reliability and validity of the results of the study the use of general scientific and special methods of cognition is provided, it is based on the foundation of dialectical logic. This approach is determined by the modern methodological context of legal science, which provides a combination of general philosophical, interdisciplinary and special scientific means of knowledge.

The methodological basis of the study is a set of methods and techniques of scientific knowledge. Their application is due to a systematic approach, which makes it possible to explore problems in the unity of their social content and legal form:

- logical-semantic method deepens the conceptual apparatus; structural-logical and comparative-legal method was used for the analysis of structural elements;

- theoretical - for the study and analysis of statistical information, scientific and methodological literature, generalization of information to determine the theoretical and methodological foundations of the study;

- logical analysis - to formulate the basic concepts and classification;

- comparative law method was used to compare the rules of foreign law;

- dogmatic method - to determine the content of legal terms used;

- concrete-historical - to demonstrate the dynamics of development;

- statistical method is used to analyze and summarize empirical information related to the research topic;

- dialectics - to establish the content and features of the constituent elements;

- empirical methods - to generalize experience;

- the method of forecasting was widely used in the dissertation in the development of proposals;

- substantivization - to move from an abstract understanding of the problems of drug distribution to the rationing and development of algorithms.

The empirical basis of the study consists of the laws of Ukraine and other domestic regulations, legal acts of the EU, the Council of Europe, and other international legal documents (Law of Ukraine..., 2010; Law of Ukraine..., 2015; 
Resolution of the Cabinet..., 2015). The study was conducted within the framework of Scientific research work No 0116 U006767 "Legal and administrative principles of cybercrime" of the Department of Cyber Security and Information Assurance Faculty of Training for Criminal Police of Odesa State University of Internal Affairs.

\section{Results and Discussion}

During the 12 months of 2019, the Anti-Crime Unit of the National Police of Ukraine documented 421 facts of sale of drugs and psychotropic substances via the Internet. It revealed 13 organized groups and 34 drug groups, which organized the scheme of sale of illicit drugs online, in particular through popular messengers. Most often, online drug stores offer their services in Kyiv, Kharkiv, Odessa, Dnipro, Mykolaiv, Kherson (Yarovyi, 2020).

In particular, in July 2019, a criminal organization for the sale of synthetic "designer" drugs were discovered by a staff of the National Police of Ukraine's Department of Drug Crime through a dedicated Internet resource. It was found that the leader of the criminal organization was a 37-year-old resident of Kyiv, who established direct deliveries of highly concentrated new psychoactive substances from the People's Republic of China to Ukraine, and recruited his IT technology relative. The latter has created a special site for the implementation of new psychoactive substances and a channel in the popular messenger and ensure their constant work and administration. All the defendants adhered to strict conspiracy, constantly changing places of dislocation and storage of psychoactive substances. High-level communication channels were used to communicate with members of the organization.

During the final stage of the special operation, 8 members of the criminal organization were detained, 26 searches were conducted and nearly 100.000 doses of drugs and psychotropes were withdrawn, kilograms of concentrate of new psychoactive substances, from which $30 \mathrm{~kg}$ of psychotropic substances can be made, worth almost 9 million UAH. Also, more than $\$ 150.000, € 12.000$ and $\$ 350.000$ worth of cash obtained from the sale of narcotic drugs, 47 bank cards, office equipment, 2 weapons, 8 vehicles were seized (Police have exposed..., 2019).

In Mykolaiv, in September 2019, employees of the Office for Combating Drug Crime liquidated the supply channel of drugs and psychotropics worth over one million hryvnias. The figures in the group 
supplied the customers with bookmarks by hiding them in nuts. They also received deliveries, disguised as postal delivery of goods from an online store. During a series of searches at the place of residence, in a car and in an apartment warehouse, law enforcement officers seized more than one kilogram of amphetamine from intruders, 150 prepared bookmarks, one and a half hundred ecstasy pills, 77 brands of LSD, cannabis, salts, about one kilogram of precursors, and other narcotics, and other drugs also bank cards and cash (In Nikolaev..., 2019). In November 2019, law enforcement officers conducted a largescale special operation to eliminate the activities of the drug syndicate, during which two organizers were detained, one of them a current member of the united territorial community, and 17 members of the criminal group. Earlier in the case, law enforcement officers from the Republic of Belarus detained two other members of the criminal organization.

For sale of manufactured goods, receiving and paying for orders, the attackers used an online store. Payment was made through a digital payment platform, ewallets or using cryptocurrency. For a conspiracy purpose, the wallets were removed and new ones created after a few days. For the proper control, functioning and security of the criminal organization, there was a clear hierarchy and division of roles: control over the functioning of laboratories, their protection, "chemists", "financiers", online store maintenance, delivery of products to storage depots, "couriers", Bookmarks and more. According to preliminary estimates, drugs and psychotropic substances were sold for almost UAH 21 million through the online store.

According to the results of almost 100 simultaneous authorized searches, the police seized more than $46 \mathrm{~kg}$ of drugs and psychotropic substances, as well as 170 liters of precursors worth UAH 25 million. In addition, \$24.000, €1100 and \$38.6 thousand, more than two dozen bank cards and mobile phones, weapons and ammunition, "draft" records containing data on "movement" of drugs, dealers, "clientele" were seized and debtors, as well as 6 premium cars (As a result..., 2019).

In order to attract potential buyers for online drug sales, sellers use specialized sites, forums (chats), ad sites, social networks, viral spam ads, which provide information about drug or psychotropic drug sales, as well as email addresses, codes, conditional terms by which you can contact the seller for a future buyer. In this case, information about an advertisement or 
offer to buy narcotic drugs or psychotropic substances may be placed in an open or veiled form.

In addition, the placement of handpainted or screen-printed drug-supply signs (so-called street graffiti) on various sites of the city's infrastructure remains quite popular. Most often you can see the words "meth", "hair dryer", "amph", "spice", "booze", "salt", “speed", "fast", “speed", "bookmarks", "treasure", "JWH", "MDMA", website addresses, popular messenger numbers (Viber, WhatsApp, Telegram, Skype, Jabber), etc. In view of this kind of drug distribution, it is a very interesting project of the Kharkiv National University of Internal Affairs, whose staff has developed a@StopDrugsBot chat bot that brings people together to counteract illegal drug trafficking to block or distribute chat bots that distribute drugs narcotic substances (Chat Bot..., 2019).

By hiding traces of their illegal activities, criminals use special techniques that substitute information about the actual addresses of their network activity, and create network resources on servers located in other countries. For example, we use a TOR browser, a proxy server that allows you to establish an anonymous traceable network connection, as well as VPN connectivity technology that creates an encrypted additional "black" network for data transmission on the Internet. When using mobile carrier numbers, sellers systematically modify their contacts to avoid possible identification. A person who wants to buy drugs through the Internet or mobile messengers contacts the seller and places the necessary order.

In return, he receives a message from the seller with a bank account number or e-wallet number for online settlement (WebMoney, Qiwi, PayPal, Q-Cash, EasyPay and others) and pays. This kind of communication can be done in various ways: online through programs such as ICQ, Skype, Viber, WhatsApp, Telegram through online correspondence in forums (chats) or using e-mail, social networks (Facebook, Twitter, Instagram), etc. (Figure 1). 


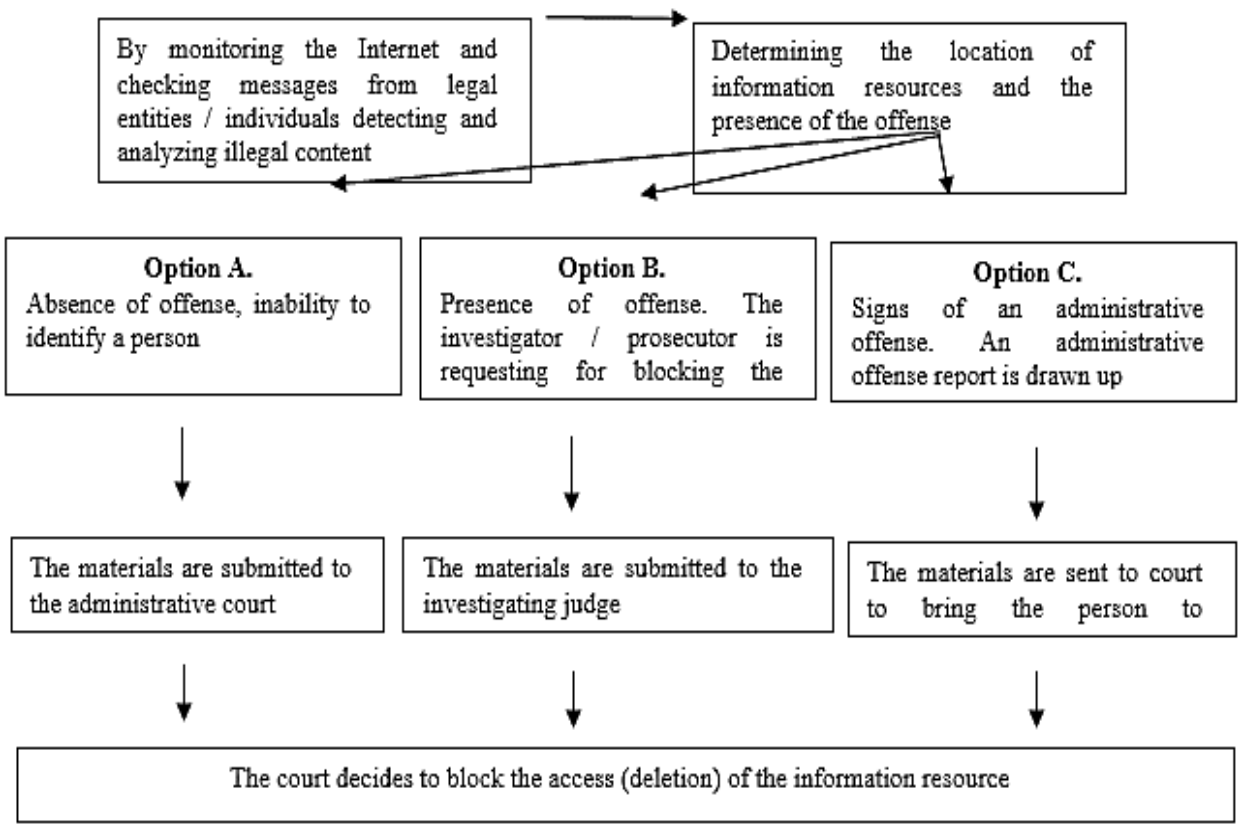

Figure 1. The mechanism of blocking the Internet resource

Source: Ismailov and Siforov (2017)

Once the Court has decided to

for its implementation, it is necessary to

block or remove an information resource

proceed as follows (Figure 2).

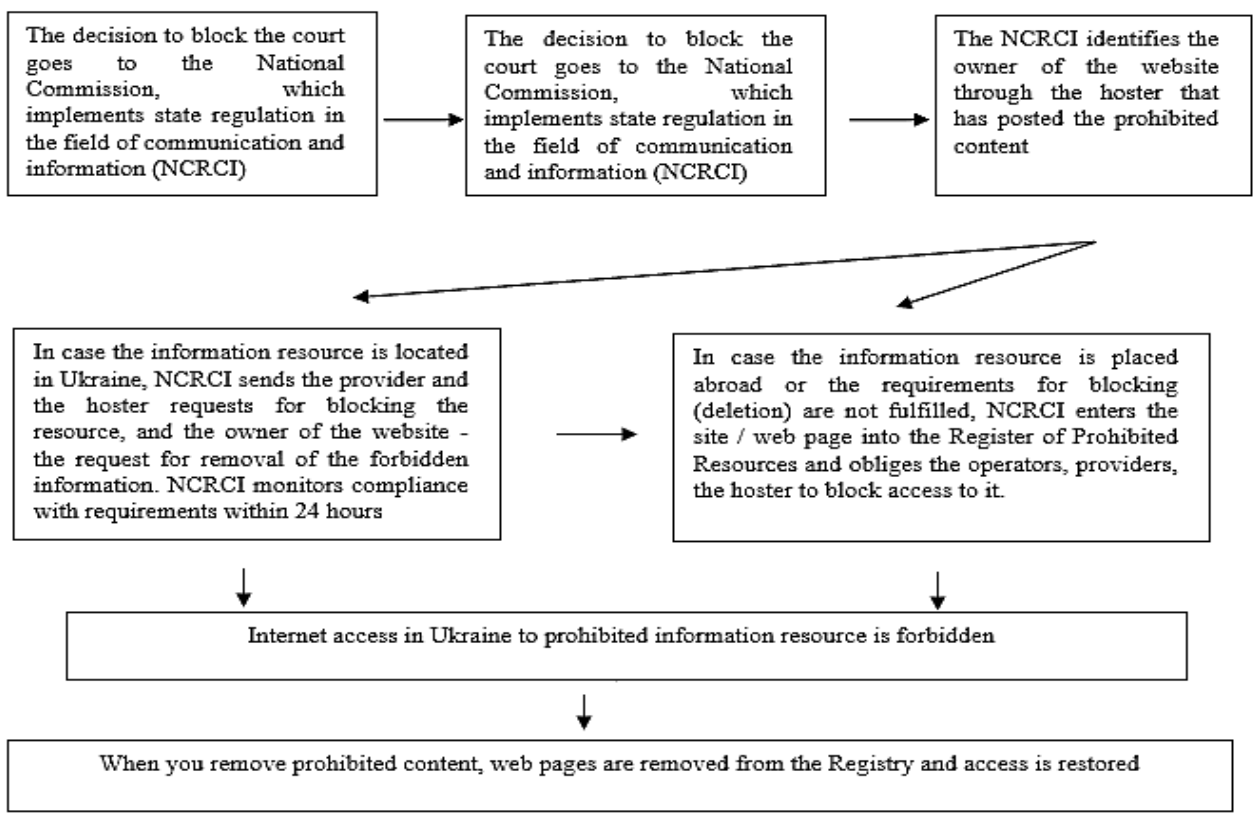

Figure 2. The mechanism of execution of the court decision on blocking the Internet resource Source: Ismailov and Siforov (2017) 
After confirming the transfer, the buyer receives a message from the seller with the address of the bookmark placement and the specific place where it is hidden (usually the message is confirmed with a photo with a geotag). Sometimes, criminals use the capabilities of Ukrposhta and private courier services (Nova Poshta, Intime, Autolux) to obtain online drug orders. After sending such parcels, the seller informs the buyer of the number of the departure declaration. Recently, for complete conspiracy and anonymity, online marketers have started using "chatbots", or in other words, virtual auto-messaging through mobile messengers that distribute drug ads via messaging and be able to support correspondence, receive orders, and answer questions.

There are a number of issues when documenting crimes in this category. One of them is that the mechanism of blocking or restricting access to Internet resources through which criminal offenses are committed or where there is prohibited content is regulated by legislation in Ukraine at an insufficient level. Thus, when detecting illegal content, law enforcement officials should be held criminally or administratively liable. This issue is of particular relevance today, especially after the President of Ukraine signed Decree No 133/2017 of May 15, 2017 "On the Application of Personal Special Economic and Other Restrictive Measures (Sanctions)", which is intended to protect the information space of the country and reduce cyberattacks for business (Decree of the President..., 2017). This requires a clear legal mechanism for the actions of persons authorized to do so, which is reflected in the scheme below.

Once the Court has decided to block or remove an information resource for its implementation, it is necessary to proceed as follows. According to paragraph 9 of Art. 38 of the Law of Ukraine "On Telecommunications", telecommunication operators and providers have the right to disconnect, on the basis of a court decision, terminal equipment if it is used by a subscriber to commit unlawful or threatening public security interests (Law of Ukraine..., 2003). However, such an algorithm is not effective enough because there is no single authority with the power to enforce court decisions to block or restrict access to illegal sites. 
Once you've installed a site that allegedly distributes narcotics or sells drugs, you need to find out where this site is technically located and which company provides the hosting service to its owners. Due to the fact that according to the register of the National Commission, which implements state regulation in the sphere of communications and information, there are more than 7 thousand Internet providers operating in the territory of Ukraine, there are certain problems in rendering a court decision requiring the blocking of illegal Internet resource (Register of telecommunications..., 2019).

If the Internet resource from which the drugs were being traded is outside Ukraine, in addition to the court order, a request for international legal assistance is also sent to the competent law enforcement agencies of foreign countries. This procedure also lacks a clear mechanism and can take a long time. In addition, in Ukraine, upon receiving a court order, telecommunications providers may report that they lack the technical capacity to block or restrict access to Internet resources. However, the legislation does not require that such equipment be required from providers. Telecommunication operators are obliged, only at their own expense, to install on their telecommunication networks the technical means necessary for carrying out by the authorized bodies of operative-investigative measures, and to ensure the functioning of these technical means, and within the limits of their powers to facilitate the conduct of operative-investigative measures and preventing the organization of investigative measures. and tactical techniques for their conduct (Law of Ukraine..., 2003).

There is also no mechanism to hold telecommunications providers accountable for failing to comply with court decisions to block websites or restrict access to prohibited content. The Verkhovna Rada of Ukraine has registered a Draft Law "On Electronic Communications" (2019), which is to replace the Law of Ukraine "On Telecommunications". In our opinion, it would be advisable to include in the said Bill the rules on temporary blocking of access to a certain information resource for the execution of the decision of the investigating judge, the court in accordance with the requirements of the criminal procedure legislation, as well as 
the storage of electronic data by the operator, provider.

It is essential to enhance the effectiveness of the fight against drug crime on the Internet by establishing full cooperation between drug and cyber police units and developing clear mechanisms to identify such crimes. In particular, cybercriminals should provide all necessary support to the local counter-narcotics units to identify both the seller and the consumer. Today, criminals are no longer using analog communication channels and classic storage sites. Increasingly, they are using cloud-based storage services and resilient hosting that is not controlled by government agencies. Therefore, it is important for National Police units to use state-of-the-art high-tech tools to produce evidence (Demediuk, 2019).

Based on the above, the issue of identifying information on illicit drug trafficking becomes more relevant, so let's look at the basic techniques for finding and analyzing information based on open sources. Increased use of wellknown search engines. As of 2019, Google.com is the most effective search engine for domain name index coverage criteria in Ukraine. Google's search engine has a User Agent - Googlebot, which is the main crawler that scans the content of a page for a search index. In addition, there are several specialized robots. Google supports search in PDF, RTF, PostScript, Microsoft Word, Microsoft Excel, Microsoft PowerPoint and more.

An important achievement of the search engine is the use of search filters and advanced search operators. Advanced Search Filters: web pages; language; country; date of update; site or domain; word placement; Safe Search; complexity of the text; file format. Advanced image search filters: size; shape; color filter; type of images (portrait, animation, etc.); site or domain; file format; safe search. Refinement of searches using operators (search keys). For more accurate results, it is advisable to use special characters or words in your queries:

- search on social networks: enter the word@ @ before the word (example: @twitter);

- price search: enter the $\$$ symbol before the amount (example: $\$ 40$ salt);

- search by hashtag (or meta category): Enter the word \# before the word (example: \#Drugs); 
- exclusion of results with certain words: enter "-" before the word to be excluded (example: speed dryer appliance);

- find the exact word or phrase:

A word or phrase in quotation marks (example: “Arcadia drug”);

- search for unknown words: enter $a^{*}$ character in the place of an unknown word in the query (example: "hair dryer * measure");

- search within the specified number range: enter .. between two numbers (example: drugs UAH 500..1000);

- query join: An OR statement is entered between queries (example: OR Olympics Olympics);

- search for a specific site or data on the specified site: enter site: before the site address or domain name (example: site: youtube.com or site: .gov);

- search for sites with similar content: enter related: before the desired web address (example: related: ukr.net); - getting information about the site: Entering info: before the web address of the site;

- search for site cache: enter cache: before web site URL.
Verification systems in many well-known mail services also allow you to retrieve phone numbers from mailboxes, or remove part of a phone number. Also, during special events it is possible to establish the presence of social network accounts (Facebook, Twitter, Instagram) in the presence of the subscriber's telephone number of the owner (Hrytenko et al., 2019).

\section{Conclusions}

Workers of the Department of Combating Drug Addiction need to quickly, effectively and comprehensively respond to the challenges of today and to qualitatively document the facts of distribution of drugs and psychotropic substances using modern information and telecommunication technologies, promptly check information from citizens about the activities of online drug stores and take measures termination. In addition, in order to improve the mechanism of blocking the Internet resource, it is necessary to develop and legislate conceptual and categorical tools, responsibilities of legal entities and individuals in the sphere of information dissemination on the Internet, as well as to amend the laws of 
Ukraine "On Information", “On Telecommunications", The Criminal Code, the Criminal Procedure Code, the Code of Administrative Offenses, the Code of Administrative Justice to prevent artificial obstacles in the exercise of their functions by executive authorities in the area of control over content on the Internet as part of a democratic society.

And to strengthen the analytical component of law enforcement in the detection and analysis of content on the Internet through the introduction of information technology into law enforcement activities, the dissemination of knowledge about OSINT (search and analysis of information based on open sources) and in general the introduction of a new philosophy of crime and law enforcement, law enforcement which is an intelligence-led law enforcement activity. Thus, the materials of the article are of practical value for the higher education graduates of police specialties, police officers of the criminal block and specialists in the field of operational search activities.

\section{References}

As a result of a large-scale special operation, the National Police exposed the syndicate of drug dealers: the value of the drugs seized is 25 million UAH. (2019).

https://www.npu.gov.ua/news/narkozloc hini/u-rezultati-masshtabnojispeczoperacziji-naczpolicziya-vikrilasindikat-narkotorgovcziv-vartistviluchenix-narkotikiv-stanovit-25miljoniv-gri.

Chat Bot in Telegram Messenger @stopdrugsbot. (2019). https://t.me/stopdrugsbot?fbclid=IwAR 1vEH8KBfywazzNRBCS9Xss5dPrnFra 2AxuUGkouJVBXcTJBhmfrE2tWbw.

Constitution of Ukraine. (1996). http://zakon3.rada.gov.ua/laws/show/25 4k/96-vr.

Council Decision No 2005/387/JHA "On the information exchange, riskassessment and control of new psychoactive substances". (2005). https://www.emcdda.europa.eu/drugslibrary/council-decision-2005387jha10-may-2005-information-exchangerisk-assessment-and-control-newpsychoactive-substances_pl. 
Decree of the President of Ukraine No $133 / 2017$ "On the decision of the National Security and Defense Council of Ukraine of April 28, 2017 "On the application of personal special economic and other restrictive measures (sanctions)".

(2017). http://www.president.gov.ua/do cuments/1332017-21850.

Degree of the Cabinet of Ministers of Ukraine No 735-p "On approval of the State Drug Policy Strategy for the period up to 2020”. (2013). https://zakon.rada.gov.ua/laws/show/73 5-2013-\%D1\%80.

Demediuk S. (2019). Law enforcement requires quality reverse engineering tools to counter modern crime. https://cyberpolice.gov.ua/news/sergijdemedyuk-dlya-protydiyi-suchasnijzlochynnosti-pravooxoronczipotrebuyut-yakisnyx-instrumentivreversnoyi-inzheneriyi-1575/.

Draft Law No 2264 "On Electronic Communications". (2019). http://w1.c1.rada.gov.ua/pls/zweb2/web proc4_1?pf3511=67082.
324

EU Drug Markets Report. (2016). https://www.europol.europa.eu/publicati ons-documents/eu-drug-markets-report2016.

Hrytenko OA, Zayets OM, Ismailov KY, Lefterov LV, Polyakov EV, Shurat TG. (2019). Guidelines on the peculiarities of disclosure and documentation of crimes related to drug trafficking, psychotropic substances, their analogues and precursors using modern telecommunications technologies. Odessa: Odessa State University of Internal Affairs.

In Nikolaev as a result of large-scale realization the police liquidated a channel of supply of drugs and psychotropes worth more than one million hryvnias. (2019). https://www.npu.gov.ua/news/narkozloc hini/u-mikolajevi-u-resultatimasshtabnoji-realizacziji-policzejskilikviduvali-kanal-postachannyanarkotikiv-ta-psixotropiv-vartistyuponad-miljon-griven/.

Ismailov KYu, Siforov OI. (2017). Legal mechanism of blocking of Internet resource in Ukraine. In: Proceedings of the International Scientific and Practical 
Conference: "State and Improvement of

Security of Information and

Telecommunication Systems", pp. 35-

39. Koblevo: MTU MP.

Law of Ukraine No 2297-VI "On

personal data protection". (2010). https://zakon.rada.gov.ua/laws/show/22

97-17.

Law of Ukraine No 580-VIII "On the

National Police".

(2015)

https://zakon.rada.gov.ua/laws/show/58

0-19.

Law of Ukraine No 1280-IV “On telecommunications".

(2003).

https://zakon.rada.gov.ua/laws/show/12

80-15.

Police have exposed a criminal organization to sell synthetic "designer" drugs through a dedicated online resource.

(2019). https://www.npu.gov.ua/news/n arkozlochini/policziya-vikrilazlochinnu-organizacziyu-u-zbutisintetichnix-dizajnerskix-narkotikivcherez-speczialnij-Internet-resurs/.

Register of telecommunications operators, providers. (2019). https://data.gov.ua/dataset/644400dc-

dc7c-4add-8593-91beb5becc68.

Resolution of the Cabinet of Ministers of Ukraine No 877 "On the National Police".

https://zakon.rada.gov.ua/laws/show/87

7-2015-\%D0\%BF.

Telegram DrugStat.

(2019).

https://t.me/joinchat/AAAAAEXcOHS

CQdfm19116w.

Yarovyi S. (2020). We need to respond to security challenges in a timely manner and not stop there. https://www.npu.gov.ua/news/golovne/ mi-povinni-vchasno-reaguvati-navikliki-u-bezpekovomu-prostori-i-nezupinyatisya-na-dosyagnutomu-sergijyarovij/ 